\title{
Understanding the Machinability of Austempered Ductile Iron (ADI)
}

\author{
Dika Handayani ${ }^{1, a^{*}}$, Robert C. Voigt ${ }^{2, b}$ and Kathy Hayrynen ${ }^{3, c}$ \\ ${ }^{1}$ Texas State University, San Marcos, TX, USA \\ ${ }^{2}$ The Pennsylvania State University, University Park, PA, USA \\ ${ }^{3}$ Applied Process Inc., Livonia, MI, USA \\ ad_h366@txstate.edu, brcv2@psu.edu, 'KHayrynen@appliedprocess.com
}

Keywords: ADI, Austempered Ductile Iron, Machining, Machinability.

\begin{abstract}
Guidelines for production milling, turning and drilling of the standard grades of austempered ductile irons (ADI) have been established. Electron Backscatter Diffraction (EBSD) characterization has clearly shown that severe plastic deformation in the machining-affected-zone, ahead of and beneath the cutting tool, will cause strain-induced martensitic transformation of the austenite in the ausferrite structure that inhibits machinability. This phenomenon is particularly of concern during finish machining where small depths of cut are strongly influenced by surface martensite from prior machining passes.
\end{abstract}

\section{Introduction}

A lack of information of machining of ADI is a startling fact in light of the growing interest in the use of ADI as an engineered material. Although narrow machining studies of ADI have been conducted, the state-of-the-art knowledge on machining ADI is still very scarce. The only machining recommendations that are currently available are provided by Klocke [1] for turning only and by Zanardi [2].

Although it is true that ADI can be all machined prior to heat treatment as an as-cast ductile iron or rough machined before and final machining after heat treatment, it is important to be able to fully machine ADI after heat treatment. The direct machining of fully heat treated ADI is especially necessary when lead time reduction and high dimensional tolerances are required.

Additional analysis on the phase transformation when machining ADI was performed. It has been suggested that the poor machinability of ADI is due to its low thermal conductivity, its tendency to work harden, and its susceptibility to martensitic transformation. The stabilized austenite in the ADI matrix structure, though thermally stable at room temperature, can be expected to have limited stability when subjected to large mechanical strains. These high plastic strain conditions can be expected at and just below a machined ADI surface in what maybe referred to as the machining-affected-zone (MAZ).

Researchers have observed that low-depth-of-cut machining operations after rough cutting of ADI are difficult to perform, but there has been no direct observation of the surface martensite transformations that can be expected to decrease machinability. Aslantas [3] used cutting force measurements as an indirect indicator of the presence of martensitic transformation. Meena [4] interpreted an increase in the hardness measurements as a sign of increasing amount of transformed austenite. Polishetty [5] measured the weight percent of martensite using XRD in addition to the cutting forces and heat-tinting metallographic analysis. EBSD will be shown to be the improved technique to directly identify the presence of transformed and deformed layer in the MAZ of ADI.

\section{Material Characterizations}

The resultant mechanical properties for the Grade 1 ADI and Grade 3 ADI obtained per ASTM E8/E8M-13a are shown in Table 1. Both Grade 1 ADI and Grade 3 ADI met the minimum mechanical properties of Grade 1 ADI and Grade 3 ADI based on ASTM A897/A897M - 16. Brinell hardness testing was completed using a $3000 \mathrm{kgf}$ load with $10 \mathrm{~mm}$ tungsten carbide ball 
indenter. In addition, the hardness was measured on the standard ductile iron Grade 100-70-03 (ascast), which was used as the reference material in facing and drilling experiments. Similarly, a common AISI 4340 steel was used as a comparison reference material for milling experiments. The hardness of the as-cast 100-70-03 ductile iron was $270 \mathrm{HBW}$, which was lower than all of the grades of ADI studied. Meanwhile, AISI 4340 steel had a bulk hardness similar to that of the Grade 2 ADI, $351 \mathrm{HBW}$. The percent austenite for Grade 1 ADI, Grade 2 ADI and Grade 3 ADI obtained by XRD were $40 \%, 37 \%$ and $30 \%$, respectively.

Table 1: Mechanical Properties of DI 100-70-03, ADI and AISI 4340 Steel

\begin{tabular}{|c|c|c|c|c|}
\hline Material & $\begin{array}{c}\text { Tensile } \\
\text { Strength } \\
\text { [ksi/MPa] }\end{array}$ & $\begin{array}{l}\text { Yield Strength } \\
\text { [(ksi/MPa] }\end{array}$ & Elongation [\%] & $\begin{array}{c}\text { Hardness } \\
\text { [HB] }\end{array}$ \\
\hline $100-70-03$ & - & - & - & 240 \\
\hline Grade 1 ADI & $150 / 1034$ & $108 / 744$ & 13 & 320 \\
\hline Grade 2 ADI & - & - & - & 357 \\
\hline Grade 3 ADI & $204 / 1406$ & $162 / 1116$ & 6 & 429 \\
\hline AISI 4340 & - & - & - & 351 \\
\hline
\end{tabular}

\section{Experimental Methods}

A series of face milling, turning and drilling experiments were conducted to evaluate the machinability of ADI. The casting scale of the ADI workpiece was removed prior to testing because the influence of surface scale was not of main interest.

Face milling experiments were carried out using a 3-insert tool configuration. The experiments were performed on a HAAS VF-2 vertical CNC Mill with the use of a large modular vise to support the workpiece (12x6x1 in). Seco ONMU090520ANTN-M14 MK2050 (TiSiN-TiAlN Nanolaminate PVD coated) was used as inserts with QuakerCool 7020-CG coolant with a 7-8\% coolant concentration. The tool life experiments were conducted according to ISO 8688-2. Useful tool life was defined as the time when an insert reached the maximum flank wear penetration (VBmax) measured from the uniform wear of $0.3 \mathrm{~mm}$ (average wear across all teeth) or localized wear of $0.5 \mathrm{~mm}$ (on any individual tooth).

Turning experiments were performed on a workpiece in the shape of a hollow cylinder with an outside diameter of 6.85 inches $(174 \mathrm{~mm})$ and an inside diameter of 4.5 inches $(114 \mathrm{~mm})$ using a HAAS ST-20 CNC Lathe. Seco CNMG120408-M5, TK 2001 inserts with Ti(C,N) + Al2O3 Duratomic CVD coatings was used in the turning trials, and QuakerCool 7020-CG with 7-8\% concentration was used as coolant. Useful tool life was defined as the time when the inserts reached a maximum flank wear penetration (VBmax) measured as $0.3 \mathrm{~mm}$. Wear land measurements were made over intervals corresponding to a constant volume of material removed (e.g., after each pass) using a stereoscope.

Drilling experiments were carried out using a HAAS VF-3 vertical CNC Mill with thru-spindle coolant capability. A $12 \times 6 \times 1$ in. $(305 \times 151 \times 25 \mathrm{~mm})$ plate workpiece was clamped on all four corners to allow for through-hole drilling. The drill used was a SECO CrownLoc Plus SD40312.00/12.49-38-16R7 (Ø $12 \mathrm{~mm})$ with SD400-12.00-P (PVD coated with TiSiN-TiAlN Nanolaminate) inserts. The drilling operations were run using QuakerCool 7020-CG coolant with 7$8 \%$ concentration. The tool life was defined as the time of drill fracture.

Metallographic samples used for sub-surface analysis were cut from rolled strip, milled plates and drilled plates. An ADI strip with a thickness of 0.125 in. was cut from the Grade 1 ADI plate. This strip was then rolled into 0.110 in. thickness in 10 passes. As for the milling samples, Grade 1 ADI plates were milled using a combination of cutting speeds of $787 \mathrm{ft} / \mathrm{min}(240 \mathrm{~m} / \mathrm{min})$ and $1575 \mathrm{ft} / \mathrm{min}(480 \mathrm{~m} / \mathrm{min})$, feed rates of $0.002 \mathrm{in} /$ tooth $(0.05 \mathrm{~mm} /$ tooth $)$ and $0.006 \mathrm{in} /$ tooth $(0.15 \mathrm{~mm} /$ tooth $)$, and depths of cut of 0.008 in $(0.2 \mathrm{~mm})$ and 0.06 in $(1.5 \mathrm{~mm})$. 
Microstructural samples were ground using 60 to 4000 grit $\mathrm{SiC}$ paper and then polished using $1 \mu \mathrm{m}$ followed by $0.3 \mu \mathrm{m}$ diamond suspension. An additional of $0.06 \mu \mathrm{m}$ colloidal silica was used for the EBSD samples. Low load Knoop microhardness $(0.3 \mathrm{kgf})$ was used to identify the change in the near-surface hardness. An EBSD imaging technique was explored to permit ferrite and martensite phases to be readily differentiated from the austenite phase.

\section{Results and Discussion}

Machining Guidelines. Table 2 summarizes the Taylor tool life models and for different grades of ADI and various machining operations. These models can be used to generate baseline machining parameters to machine commercial grades of ADI for a given expected tool life. The recommended starting parameters to machine different grades of ADI using tool life variations for cutting speed recommendations are also shown in this table. The importance of establishing this relationship is the ability to fulfill the different preferences that came from the machine shops (i.e. productivity vs. cost). When a high productivity level is required, the use of high cutting speed is desirable. However, this will also mean that the tool will wear at a faster rate, and thus, the tooling cost will increase. Expressing machining recommendations and ranges using "tool life ranges" will be an effective way for machine shops to readjust cutting speeds during initial production machining trials to establish the desired cutting speed for appropriate tool life.

Multiple linear regression analysis was performed on data obtained from the series of face milling experiments to estimate the machinability constants in a modified Taylor tool life equation $\left(\mathrm{V} \mathrm{T}^{\mathrm{x}} \mathrm{f}^{\mathrm{y}} \mathrm{d}^{\mathrm{z}}=\mathrm{C}\right)$ for Grade 1 ADI and Grade 3 ADI. From these constants, it can be observed that tool life was most sensitive to the change in cutting speed followed by the feed rate and depth of cut when machining Grade 1 ADI. In production machining, small improvements in tool life can result in significant cost savings.

While positive values for the constants $\mathrm{x}, \mathrm{y}$ and $\mathrm{z}$ in modified Taylor tool life equations $\left(\mathrm{V} \mathrm{T}^{\mathrm{x}} \mathrm{f}^{\mathrm{y}}\right.$ $\mathrm{d}^{\mathrm{z}}=\mathrm{C}$ ) are typically obtained, a negative value for the constant $\mathrm{z}$ (corresponding to depth of cut) was observed when machining ADI. This implied that tool life increased with a deeper depth of cut. This phenomena was in agreement with general advice that a lower cutting speed with a deeper cut is required to increase the tool life when machining ADI [6]. Small depths of cut are believed to be detrimental to tool life due to strain-induced surface martensite transformation that occurs during machining ADI. When a deeper cut is taken, the proportion of this surface martensite removed during cutting becomes less significant in comparison to the bulk of the material being removed.

Milling parameters with coated carbide and coolant recommended for milling ADI are presented in Table 2. It must be noted that $420 \mathrm{~m} / \mathrm{min}$ and $380 \mathrm{~m} / \mathrm{min}$ are the maximum limit of cutting speeds to mill Grade 1 ADI and Grade 2 ADI. A cutting speed of $120 \mathrm{~m} / \mathrm{min}$ and $280 \mathrm{~m} / \mathrm{min}$ are set to be the lower and upper boundary of cutting speeds used to mill Grade 3 ADI.

It should be pointed out that the turning tool wear studies and the initial turning recommendations in this study are based on the measurement of secondary flank wear rather than primary flank wear. The tool wear results obtained from the secondary flank wear measurements used in this study are effective and reliable because of similar measurements were observed in the steady-state wear region and a slight difference in the break-in period and failure region. However, this difference is considered insignificant. The observation of similar wear measurements on the major and minor flank faces of carbide inserts were also confirmed by Masuda et. al. [7]. This similarity in wear measurements on both flank faces is also observed when machining TRIP material such as Hadfield steel. Kuljanic et. al. [8] noticed severe wear both on the major flank face, the minor flank face and the rake face.

The recommended turning speeds from this study were comparable and slightly higher than those recommended by Zanardi [2]with the exception of Grade 3 ADI. It should also be noted that slightly higher feed rates and lower depths of cut were used in this study.

Unlike in milling and turning operations, careful data analysis suggested that the drilling feed was the main factor that affected the drill life followed by the cutting speed. An increase in the feed 
rate was believed to cause a higher temperature rise in the drill than an increase in the drilling speed. This effect was more pronounced with increasing material hardness.

In general, ADIs should be machined at $25 \%$ lower cutting speeds than conventional steels with comparable bulk hardness. Although similar patterns of flank wear were observed when machining ADI and steel of similar overall hardness, higher levels of crater wear were observed when machining ADI [1]. Because of the presence of graphite in Grade 2 ADI microstructure, even though its bulk hardness was similar to that of the AISI 4340 steel, it can be expected that the matrix hardness of the Grade 2 ADI was significantly higher than its bulk hardness. Therefore, the expected tool life for AISI 4340 would last longer than that used to machine Grade 2 ADI of similar hardness overall. Similarly, appropriate cutting speed for machining the widely used Grade 1 ADI are 25\% lower than cutting speeds used for grade 100-70-03 as-cast ductile iron.

Table 2: ADI Taylor Tool Life Models and ADI Machining Recommendations for Various Expected Tool Life

\begin{tabular}{|c|c|c|c|}
\hline \multirow{2}{*}{ ADI Grade } & \multicolumn{3}{|c|}{ Taylor Tool Life Equations } \\
& \multicolumn{3}{|c|}{$\mathrm{V}[\mathrm{ft} / \mathrm{min}]-\mathrm{T}[\mathrm{min}]-\mathrm{f}[\mathrm{in} . / \mathrm{rev}]-\mathrm{d}[\mathrm{in}]}$. \\
\cline { 2 - 4 } & Face Milling & Turning & Drilling \\
\hline Grade 1 ADI & $\mathrm{V} \mathrm{T}^{0.40} \mathrm{f}^{0.17} \mathrm{~d}^{-0.08}=1588$ & $\mathrm{~V} \mathrm{~T}^{0.37}=1617$ & $\mathrm{~V} \mathrm{~T}^{0.38} \mathrm{f}^{1.04}=11.9$ \\
\hline Grade 2 ADI & & $\mathrm{V} \mathrm{T}^{0.33}=1338$ & \\
\hline Grade 3 ADI & $\mathrm{V} \mathrm{T}^{0.38} \mathrm{f}^{0.04} \mathrm{~d}^{-0.13}=2185$ & $\mathrm{~V} \mathrm{~T}^{0.26}=721$ & $\mathrm{~V} \mathrm{~T}^{0.58} \mathrm{f}^{1.78}=0.19$ \\
\hline
\end{tabular}

MILLING

\begin{tabular}{|c|c|c|c|c|c|c|}
\hline \multirow{3}{*}{$\begin{array}{l}\text { Tool Life (T) } \\
\mathbf{T}=15 \mathrm{~min}\end{array}$} & \multicolumn{6}{|c|}{$\begin{aligned} &\text { Cutting speed [ft } / \mathbf{m i n}]-\mathbf{f}=\mathbf{0 . 0 0 3} \mathbf{~ i n} / \mathbf{t o o t h} \\
& \text { Cutting speed }[\mathrm{m} / \mathrm{min}]-f=0.08 \mathrm{~mm} / \text { tooth }\end{aligned}$} \\
\hline & \multicolumn{2}{|c|}{ Grade 1 ADI } & \multicolumn{2}{|c|}{ Grade 2 ADI } & \multicolumn{2}{|c|}{ Grade 3 ADI } \\
\hline & $\begin{array}{c}\mathbf{d}=\mathbf{0 . 0 4} \text { in } \\
1.0 \mathrm{~mm}\end{array}$ & $\begin{array}{c}\mathbf{d}=\mathbf{0 . 0 6} \text { in } \\
1.5 \mathrm{~mm}\end{array}$ & $\begin{array}{c}\mathbf{d}=\mathbf{0 . 0 4} \text { in } \\
1.0 \mathrm{~mm}\end{array}$ & $\begin{array}{c}\mathbf{d}=\mathbf{0 . 0 6} \text { in } \\
1.5 \mathrm{~mm}\end{array}$ & $\begin{array}{c}\mathbf{d}=\mathbf{0 . 0 4} \text { in } \\
1.0 \mathrm{~mm}\end{array}$ & $\begin{array}{c}\mathbf{d}=\mathbf{0 . 0 6} \text { in } \\
1.5 \mathrm{~mm}\end{array}$ \\
\hline $2 \mathrm{~T}$ & $\begin{array}{l}700 \\
210\end{array}$ & $\begin{array}{l}720 \\
220\end{array}$ & $\begin{array}{l}\mathbf{6 1 0} \\
185\end{array}$ & $\begin{array}{l}630 \\
190\end{array}$ & $\begin{array}{l}470 \\
140\end{array}$ & $\begin{array}{l}\mathbf{5 0 0} \\
150\end{array}$ \\
\hline $\mathbf{T}+5$ & $\begin{array}{l}820 \\
250\end{array}$ & $\begin{array}{l}850 \\
260\end{array}$ & $\begin{array}{l}720 \\
220\end{array}$ & $\begin{array}{l}740 \\
225\end{array}$ & $\begin{array}{l}\mathbf{5 5 0} \\
165\end{array}$ & $\begin{array}{l}\mathbf{5 8 0} \\
175\end{array}$ \\
\hline $\mathbf{T}$ & $\begin{array}{l}900 \\
275\end{array}$ & $\begin{array}{l}\mathbf{9 5 0} \\
290\end{array}$ & $\begin{array}{l}\mathbf{8 1 0} \\
245\end{array}$ & $\begin{array}{l}\mathbf{8 3 0} \\
250\end{array}$ & $\begin{array}{l}\mathbf{6 2 0} \\
190\end{array}$ & $\begin{array}{l}\mathbf{6 5 0} \\
200\end{array}$ \\
\hline $\mathbf{T}-\mathbf{5}$ & $\begin{array}{c}\mathbf{1 0 8 0} \\
330\end{array}$ & $\begin{array}{c}\mathbf{1 1 2 0} \\
340\end{array}$ & $\begin{array}{l}950 \\
290\end{array}$ & $\begin{array}{r}980 \\
300\end{array}$ & $\begin{array}{l}720 \\
220\end{array}$ & $\begin{array}{l}760 \\
230\end{array}$ \\
\hline $0.5 T$ & $\begin{array}{c}\mathbf{1 2 2 0} \\
370\end{array}$ & $\begin{array}{c}\mathbf{1 2 6 0} \\
385\end{array}$ & $\begin{array}{c}\mathbf{1 0 7 0} \\
325\end{array}$ & $\begin{array}{c}1100 \\
335\end{array}$ & $\begin{array}{l}800 \\
245\end{array}$ & $\begin{array}{l}\mathbf{8 5 0} \\
260\end{array}$ \\
\hline
\end{tabular}

TURNING

\begin{tabular}{|c|c|c|c|}
\hline \multirow{2}{*}{$\begin{array}{l}\text { Tool Life (T) } \\
T=15 \mathrm{~min} \\
\end{array}$} & \multicolumn{3}{|c|}{$\begin{aligned} &\text { Cutting speed [ft } / \mathbf{m i n}]-\mathbf{f}=\mathbf{0 . 0 1 2} \mathrm{in} / \mathbf{r e v}-\mathbf{d}=\mathbf{0 . 0 6 0} \text { in. } \\
& \text { Cutting speed }[\mathrm{m} / \mathrm{min}]-f=0.30 \mathrm{~mm} / \mathrm{rev}-d=1.5 \mathrm{~mm}\end{aligned}$} \\
\hline & Grade 1 ADI & Grade 2 ADI & Grade 3 ADI \\
\hline $2 \mathrm{~T}$ & $\begin{array}{l}455 \\
140\end{array}$ & $\begin{array}{l}430 \\
130\end{array}$ & $\begin{array}{c}300 \\
90\end{array}$ \\
\hline $\mathbf{T}+\mathbf{5}$ & $\begin{array}{l}\mathbf{5 3 0} \\
160\end{array}$ & $\begin{array}{l}\mathbf{5 0 0} \\
150\end{array}$ & $\begin{array}{l}335 \\
100 \\
\end{array}$ \\
\hline $\mathbf{T}$ & $\begin{array}{l}\mathbf{5 8 5} \\
175\end{array}$ & $\begin{array}{l}550 \\
165\end{array}$ & $\begin{array}{l}360 \\
110\end{array}$ \\
\hline $\mathbf{T}-\mathbf{5}$ & $\begin{array}{l}\mathbf{6 8 0} \\
205\end{array}$ & $\begin{array}{l}625 \\
190\end{array}$ & $\begin{array}{l}400 \\
120\end{array}$ \\
\hline $0.5 T$ & $\begin{array}{l}760 \\
230\end{array}$ & $\begin{array}{l}685 \\
210\end{array}$ & $\begin{array}{l}430 \\
130\end{array}$ \\
\hline
\end{tabular}


DRILLING

\begin{tabular}{|c|c|c|c|c|c|c|c|c|}
\hline \multirow{3}{*}{$\begin{array}{c}\text { Tool Life } \\
\quad \text { (T) } \\
T=15 \text { min }\end{array}$} & \multicolumn{8}{|c|}{$\begin{array}{c}\text { Drilling speed [ft } / \mathbf{m i n}]-\mathbf{d}=\mathbf{1} \text { in. } \\
\text { Drilling speed }[\mathrm{m} / \mathrm{min}]-d=25 \mathrm{~mm}\end{array}$} \\
\hline & \multicolumn{3}{|c|}{ Grade 1 ADI } & \multicolumn{3}{|c|}{ Grade 2 ADI } & \multicolumn{2}{|c|}{ Grade 3 ADI } \\
\hline & $\begin{array}{c}\text { 0.009 ipr } \\
0.23 \\
m m / r\end{array}$ & $\begin{array}{c}\mathbf{0 . 0 1 1} \\
\text { ipr } \\
0.29 \\
m m / r e \\
v\end{array}$ & $\begin{array}{c}\text { 0.017 ipr } \\
\\
0.43 \\
\mathrm{~mm} / \mathrm{rev}\end{array}$ & $\begin{array}{c}\text { 0.009 ipr } \\
0.23 \\
\mathrm{~mm} / \mathrm{rev}\end{array}$ & $\begin{array}{c}\mathbf{0 . 0 1 1} \\
\text { ipr } \\
0.29 \\
m m / r e \\
v\end{array}$ & $\begin{array}{c}\text { 0.017 ipr } \\
\\
0.43 \\
\mathrm{~mm} / \mathrm{rev}\end{array}$ & $\begin{array}{c}\text { 0.006 ipr } \\
0.15 \\
\mathrm{~mm} / \mathrm{rev}\end{array}$ & $\begin{array}{c}\mathbf{0 . 0 0 9} \\
\text { ipr } \\
0.23 \\
m m / r e \\
v\end{array}$ \\
\hline $2 \mathrm{~T}$ & $\begin{array}{l}445 \\
135 \\
\end{array}$ & $\begin{array}{l}\mathbf{3 6 0} \\
110 \\
\end{array}$ & $\begin{array}{c}230 \\
70 \\
\end{array}$ & $\begin{array}{l}\mathbf{4 0 0} \\
120\end{array}$ & $\begin{array}{l}325 \\
100 \\
\end{array}$ & $\begin{array}{c}205 \\
65 \\
\end{array}$ & $\begin{array}{c}215 \\
65 \\
\end{array}$ & $\begin{array}{c}\mathbf{1 0 5} \\
30 \\
\end{array}$ \\
\hline $\mathbf{T}+5$ & $\begin{array}{l}\mathbf{5 2 0} \\
160\end{array}$ & $\begin{array}{l}420 \\
130\end{array}$ & $\begin{array}{c}265 \\
80\end{array}$ & $\begin{array}{l}470 \\
145 \\
\end{array}$ & $\begin{array}{l}380 \\
115 \\
\end{array}$ & $\begin{array}{c}240 \\
70\end{array}$ & $\begin{array}{c}270 \\
80\end{array}$ & $\begin{array}{c}135 \\
40 \\
\end{array}$ \\
\hline $\mathbf{T}$ & $\begin{array}{l}\mathbf{5 8 0} \\
175\end{array}$ & $\begin{array}{l}470 \\
145\end{array}$ & $\begin{array}{c}300 \\
90\end{array}$ & $\begin{array}{l}\mathbf{5 2 0} \\
155\end{array}$ & $\begin{array}{l}425 \\
130\end{array}$ & $\begin{array}{c}270 \\
80\end{array}$ & $\begin{array}{c}320 \\
95\end{array}$ & $\begin{array}{c}155 \\
50\end{array}$ \\
\hline$T-5$ & $\begin{array}{l}\mathbf{6 8 0} \\
205\end{array}$ & $\begin{array}{l}\mathbf{5 5 0} \\
165\end{array}$ & $\begin{array}{l}350 \\
105\end{array}$ & $\begin{array}{l}\mathbf{6 1 0} \\
185\end{array}$ & $\begin{array}{l}495 \\
150\end{array}$ & $\begin{array}{c}315 \\
95\end{array}$ & $\begin{array}{l}405 \\
125\end{array}$ & $\begin{array}{c}200 \\
60\end{array}$ \\
\hline $0.5 \mathrm{~T}$ & $\begin{array}{l}755 \\
230\end{array}$ & $\begin{array}{l}\mathbf{6 0 0} \\
180\end{array}$ & $\begin{array}{l}390 \\
120\end{array}$ & $\begin{array}{l}\mathbf{6 8 0} \\
205\end{array}$ & $\begin{array}{l}\mathbf{5 4 0} \\
165\end{array}$ & $\begin{array}{l}350 \\
105\end{array}$ & $\begin{array}{l}475 \\
145\end{array}$ & $\begin{array}{c}230 \\
70\end{array}$ \\
\hline
\end{tabular}

Machining-Affected-Zones. Although microhardness measurements are commonly used to indicate surface hardening phenomena, the machining-affected-zone (MAZ) transformed layer is very thin and it is not possible to differentiate between transformed, deformed and the overall machining-affected layer (Fig. 1) with microhardness measurements alone. A characteristic Knoop hardness has a width of approximately $17 \mu \mathrm{m}$. This width is more than the expected thickness of the transformed layer, which may be only $5-10 \mu \mathrm{m}$ in depth. Furthermore, the required distance from specimen edge must also be considered when performing hardness measurements.

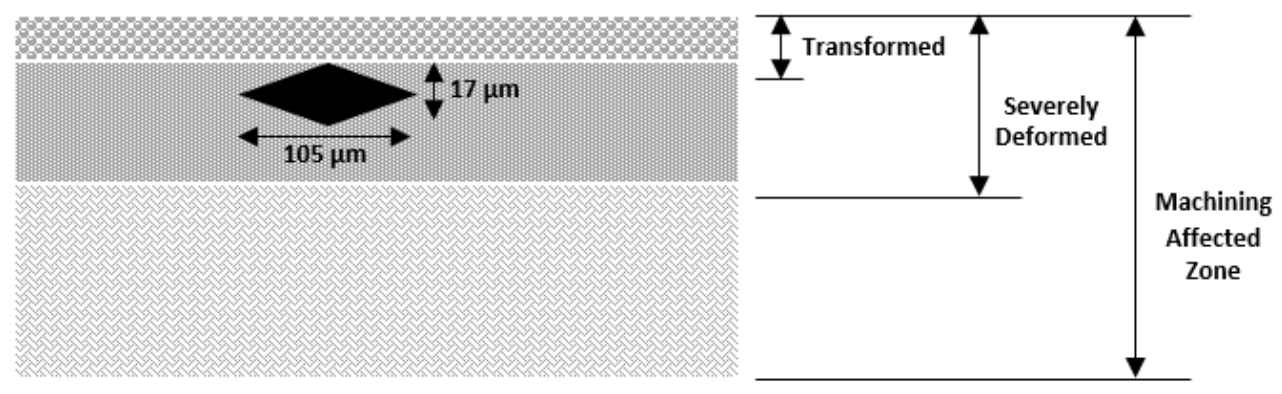

Fig. 1: Machining-affected-zone (MAZ) consists of three different layers

Fig. 2(a) shows surface microhardness measurements for Grade 1 ADI compared to Grade 1 ADI rolled from an initial thickness of 0.125 in. to a final thickness of 0.110 in $(12.7 \%$ plastic strain). An average hardness for untreated Grade 1 ADI was found to be $387 \mathrm{HK}$ (Knoop hardness). Increased surface hardness measurements for the rolled sample can be expected due to strain hardening of the surface layers. Average microhardness for the rolled near the surface at a distance of less than $400 \mu \mathrm{m}(0.015 \mathrm{in})$ and under the rolled surface at a distance of greater than $400 \mu \mathrm{m}$ ( $0.015 \mathrm{in}$ ) were $503 \mathrm{HK}$ and $441 \mathrm{HK}$ respectively. While some strain-hardening of the ausferrite is suggested from the microhardness measurements, this method cannot be used to clearly identify any possible austenite transformation to martensite, especially in the surface zone in the near surface layer less than $50 \mu \mathrm{m}$ below the surface. This drawback is reflected in surface microhardness measurements for Grade 1 ADI shown in Fig. 2(b). Since the first microhardness measurements were taken at $50 \mu \mathrm{m}$ below the surface, there are no sign of strain-hardening detected. Any microstructural transformation and deformation occurred within $50 \mu \mathrm{m}$ below the surface was not captured by the microhardness measurements. It must also be noted that the microhardness measurements on ADI are challenging due to the presence of subsurface graphite.

Fig. 3 shows the microhardness measurements of Grade 1 ADI drilled at different machining parameters. Significantly high microhardness measurements were observed when the tests were 
done at $10 \mu \mathrm{m}$ below the machined surface. However, these measurements might be inaccurate due to insufficient distance from the sample edge. In addition, while higher microhardness measurements indicate some strain-hardening of ausferrite, it does not mean that martensitic transformation also occurs.

An increase in hardness measurements was found on Grade 1 ADI up to $150 \mu \mathrm{m}$ (0.006 in) from the drilled surface. The higher hardness measurements was found at low feed rates $(0.29 \mathrm{~mm} / \mathrm{rev})$. Therefore, low feed rates during drilling must be avoided to minimize drill dwelling and the work hardening. High surface hardness also occurred at the highest drilling speeds and feed rates with worn drills. This outcome can be expected as a result of increased plastic strain and higher cutting temperatures under these drilling conditions.
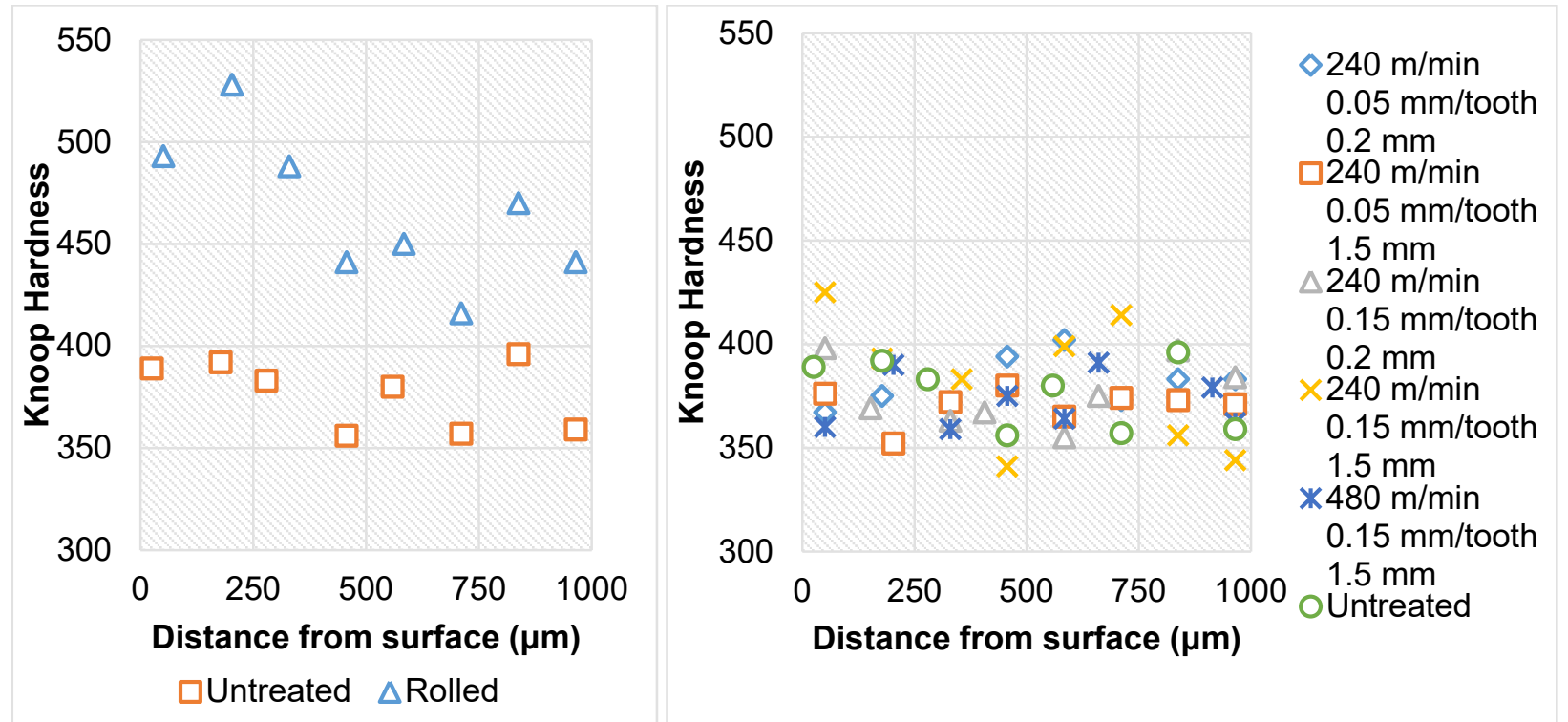

Fig. 2: Knoop microhardness of (a) untreated and cold-rolled sample, and (b) milled samples of Grade 1 ADI machined with different milling parameters

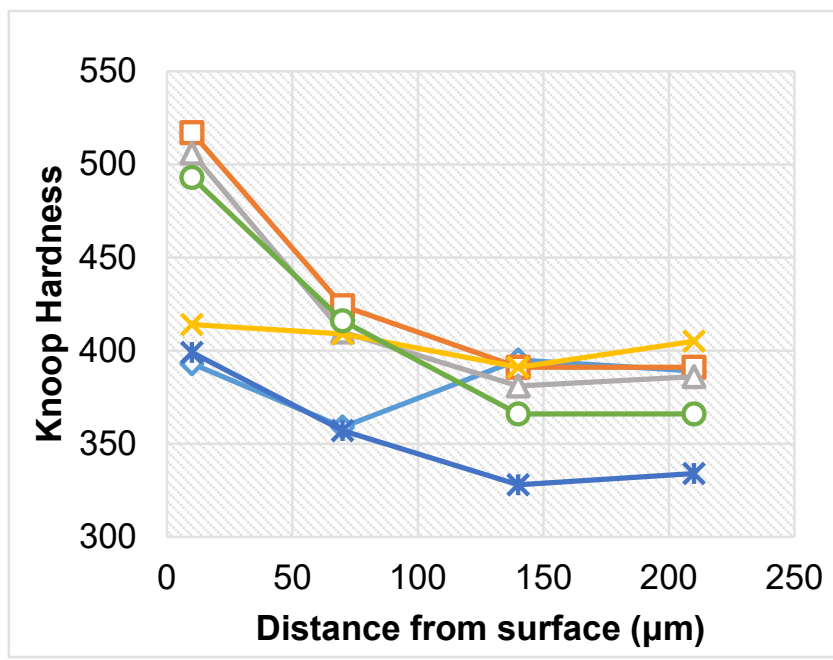

$$
\begin{gathered}
-110 \mathrm{~m} / \mathrm{min} ; 0.29 \\
\mathrm{~mm} / \mathrm{rev} ; 21 \text { holes } \\
-\square-110 \mathrm{~m} / \mathrm{min} ; 0.29 \\
\mathrm{~mm} / \mathrm{rev} ; 720 \text { holes } \\
-\triangle 150 \mathrm{~m} / \mathrm{min} ; 0.29 \\
\mathrm{~mm} / \mathrm{rev} ; 21 \text { holes } \\
\times-150 \mathrm{~m} / \mathrm{min} ; 0.29 \\
\mathrm{~mm} / \mathrm{rev} ; 594 \text { holes } \\
*-150 \mathrm{~m} / \mathrm{min} ; 0.43 \\
\mathrm{~mm} / \mathrm{rev} ; 21 \text { holes } \\
-150 \mathrm{~m} / \mathrm{min} ; 0.43 \\
\mathrm{~mm} / \mathrm{rev} ; 288 \text { holes }
\end{gathered}
$$

Fig. 3: Hardness of drilled samples of Grade 1 ADI using different drilling parameters

Improved surface layer metallographic analysis is possible using EBSD. EBSD imaging techniques allow the ferrite and martensite phases to be readily differentiated from the austenite phase. In addition, EBSD can also be used to better identify the MAZ microstructure and texture (both deformed and transformed zone).

Fig. 4 shows the EBSD image (ferrite phase highlighted) for milled sample of Grade 1 ADI at the sub-surface. EBSD readily shows the thickness of MAZ region indicated by the deformed region (color shift due to an orientation shift) and the transformed layer (more ferrite due to transformation of austenite to martensite). Martensite is visible in the ferrite window because of its 
BCT (body-centered tetragonal) crystalline structure. This image not only shows the change in the grain orientation of ADI but also clearly shows that phase transformation of deformed austenite to martensite occurred on the sub-surface of the milled ADI. A total thickness of $12 \mu \mathrm{m} \mathrm{MAZ} \mathrm{with}$ $4 \mu \mathrm{m}$ deep of transformed region is clearly observed in this milling sample.

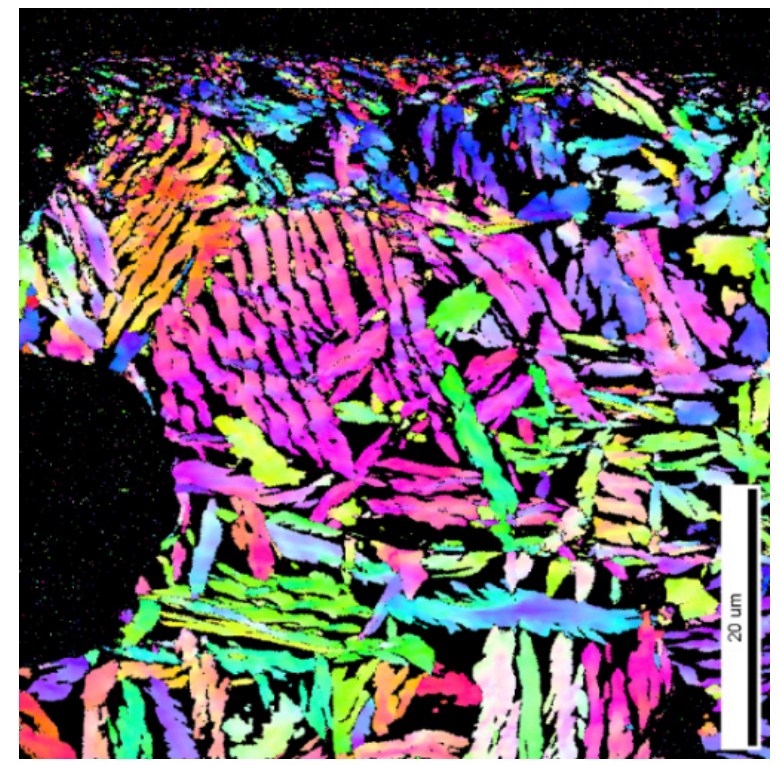

Fig. 4: Milling samples of Grade 1 ADI (ferrite phase) characterized using EBSD

\section{Conclusions}

Comprehensive machining recommendations for the commercial grades of ADI have been generated. This information is critical to drive further applications of ADI as an engineering material. Strain-induced martensitic transformation of the ausferrite is observed on prior machined surfaces. Sufficient depth of cut and feed rate must be used when machining ADI to not only maintain the cut below the surface martensitic layer but also below the work-hardened layer to avoid lower tool life during subsequent passes.

\section{References}

[1] F. Klocke and C. Klopper, Machining of ADI, Aachen, Germany, pp. 1-10, 2013.

[2] F. Zanardi, The Development of Machinable ADI in Italy, International Scientific Conference "Ductile Iron in the 21st Century, 2003.

[3] K. Aslantas, I. Ucun, and K. Gök, Evaluation of the Performance of CBN Tools When Turning Austempered Ductile Iron Material, J. Manuf. Sci. Eng., vol. 130, no. 5, 2008.

[4] A. Meena and M. El Mansori, Drilling performance of green austempered ductile iron (ADI) grade produced by novel manufacturing technology, Int. J. Adv. Manuf. Technol., vol. 59, no. 1-4, pp. 9-19, 2012.

[5] A. Polishetty, G. Littlefair, and T. Pasang, A Case Study on Effect of Feed Rate on Machinability of Austempered Ductile Iron, Adv. Mater. Res., vol. 748, pp. 247-251, 2013.

[6] K. Brandenberg, Successfully Machining Austempered Ductile Iron ( ADI ), 2001.

[7] M. Masuda, T. Sato, T. Kori, and Y. Chujo, Cutting performance and wear mechanism of alumina-based tools when machining austempered ductile iron, Wear, vol. 174, pp. 147-153, 1994.

[8] E. Kuljanic, M. Sortino, G. Totis, and F. Prosperi, Evaluation Of Commercial Tools For Machining Special-Alloy Hadfield Steel. 